Check for updates

Cite this: RSC Adv., 2017, 7, 39391

\title{
Comparison of the exergy efficiency of four power generation systems from methane using fuel cells
}

\begin{abstract}
Zhe Wang, (D) *a Weiyu Fan ${ }^{\mathrm{b}}$ and Guangqing Zhang ${ }^{\mathrm{c}}$
Exergy analyses are carried out on four different solid oxide fuel cell (SOFC) systems using methane as the original fuel, with focus on exergy flows, efficiency and destruction. The four processes are (1) $\mathrm{CH}_{4}-\mathrm{SOFC}$, which is a $\mathrm{CH}_{4}$ directly fuelled SOFC system with a $\mathrm{CO}_{2}$ capture unit; (2) $\mathrm{CH}_{4}$-SOFC-CLC, in which the $\mathrm{CH}_{4}$-SOFC system is integrated with chemical looping combustion (CLC); (3) SMR-SOFC, i.e. a SOFC system using $\mathrm{H}_{2}\left(\mathrm{H}_{2}\right.$-SOFC) generated by steam methane reforming (SMR); (4) MC-SOFC-DCFC, which is a combined system of $\mathrm{H}_{2}$-SOFC and a direct carbon fuel cell (DCFC) where $\mathrm{H}_{2}$ and $\mathrm{C}$ are supplied by methane cracking (MC). Generally, the $\mathrm{CH}_{4}$-SOFC and $\mathrm{CH}_{4}$-SOFC-CLC processes which directly use $\mathrm{CH}_{4}$ as the fuel of cells have higher exergy efficiency. MC-SOFC-DCFC reaches an overall exergy efficiency of $71.4 \%$, which is $17 \%$ higher than that of SMR-SOFC $(54.4 \%)$ due to the higher exergy efficiency of MC than SMR. The effects of operating parameters on the performance of $\mathrm{CH}_{4}$-SOFC are also examined in detail. The results of this investigation demonstrate that the development of methane directly fuelled SOFC, decreasing its operating temperature and suitable capture of $\mathrm{CO}_{2}$ are the key technologies to improve the energy conversion efficiency of methane fuelled SOFC systems.
\end{abstract}

Received 9th May 2017

Accepted 1st August 2017

DOI: 10.1039/c7ra05245f

rsc.li/rsc-advances
Since the reaction is highly endothermic, huge amounts of supplemental energy is required to maintain the reforming temperature. The energy is usually provided by the combustion of additional methane (if necessary) or the off-gas from the $\mathrm{H}_{2}$ purification unit, which resulting in high $\mathrm{CO}_{2}$ emissions and a relatively low energy efficiency of SMR (60-75\%).,5

Nowadays, it has been increasingly necessary to investigate and develop low $\mathrm{CO}_{2}$ emission technologies owing to the greenhouse gas (GHG) concerns. In comparison with SMR, methane cracking (MC), as described by reaction (2), is a new alternative to hydrogen production due to its simplicity of process and the absence of $\mathrm{CO}_{x}$ by-product. ${ }^{6}$

$$
\mathrm{CH}_{4}(\mathrm{~g})=\mathrm{C}(\mathrm{s})+2 \mathrm{H}_{2}(\mathrm{~g}), \Delta H_{298 \mathrm{~K}}=74.6 \mathrm{~kJ}
$$

When the temperature is higher than $600{ }^{\circ} \mathrm{C}$, the methane cracking reaction can occur at a reasonable rate. As the only gaseous product, hydrogen can be easily separated from the unreacted methane via membrane or adsorption separation, which is much simpler compared to the complex purification processes that also deal with $\mathrm{CO}_{2}$ and $\mathrm{CO}$ in SMR. The produced solid carbon has value as a replacement for carbon black or can serve as the fuel of a direct carbon fuel cell (DCFC). ${ }^{7,8}$ Liu et al. ${ }^{8}$ proposed an energy conversion system on the basis of a MC reactor together with two fuel cells. In this model, the hydrogenrich product of MC was used in an internal reforming solid oxide fuel cell (IRSOFC) and the carbon generated via MC was fed into a DCFC. An exergy efficiency of $68.2 \%$ was proposed in that system. Previously, we conducted detailed comparative
${ }^{a}$ State Key Laboratory of Advanced Metallurgy, University of Science and Technology Beijing, Beijing 100083, China.E-mail: zhewang@ustb.edu.cn

${ }^{b}$ State Key Laboratory of Heavy Oil Processing, China University of Petroleum, Qingdao, Shandong 266580, China

'School of Mechanical, Materials and Mechatronic Engineering, University of Wollongong, NSW 2522, Australia 
exergy analysis of three $\mathrm{MC}$ processes with different $\mathrm{CO}_{2}$ capture methods. It is demonstrated that these MC processes can achieve global exergy efficiencies close to $90 \%{ }^{9}$

The application of $\mathrm{CO}_{2}$ capture and storage (CCS) techniques is another promising option of reducing $\mathrm{CO}_{2}$ emissions, which includes pre-combustion capture, post-combustion capture and capture in oxy-combustion. ${ }^{\mathbf{1 0}}$ Unfortunately all these methods require expensive and complicated equipment and have low energy efficiency due to the high energy penalty. As an attractive technology, the chemical looping combustion (CLC) process emerges which is capable of obtaining inherent separation of $\mathrm{CO}_{2} \cdot{ }^{11}$ In CLC, the fuel combustion is divided into two subreactions tanking place in two separate reactors, i.e., a fuel reactor (FR) and an air reactor (AR). A metal oxide as oxygen carriers (OCs) is circled in CLC to oxidise fuel in FR and to be reoxidised in AR by fresh air. The off-gas from FR mainly contains $\mathrm{CO}_{2}$ and water vapour. After water vapour condensation, a highly concentrated $\mathrm{CO}_{2}$ stream ready for transport and storage is obtained. More detailed process description of CLC can be found elsewhere. ${ }^{12,13}$

Originally, the CLC was proposed to combine with gas turbines for electricity production..$^{11,14,15}$ Later, proposals on the application of CLC for $\mathrm{H}_{2}$ production have been expanded significantly over the last 10 years, e.g. SMR integrated with CLC (SMR-CLC), ${ }^{5,16-18}$ auto-thermal chemical-looping reforming (CLR) ${ }^{19,20}$ and MC integrated with CLC (MC-CLC). ${ }^{9}$ Chen et al. ${ }^{21}$ recently incorporated a coal gasification process with SOFC and CLC. The predicted plant net power efficiency is about $49.8 \%$ with complete $\mathrm{CO}_{2}$ separation. The thermodynamics of CLC-GT, ${ }^{11,14,15}$ SMR-CLC ${ }^{16,17}$ and CLR $^{19,20}$ have been intensively studied. Nevertheless, investigations on process simulation and thermodynamics of the processes of the SOFC integrated with CLC and the MC integrated with fuel cells are limited. ${ }^{21}$

The objective of this paper is, by means of energy and exergy analyses, to evaluate and compare four different fuel cell processes which use methane as the original fuel, including (1) $\mathrm{CH}_{4}$-SOFC, i.e. $\mathrm{CH}_{4}$ directly fuelled SOFC with a $\mathrm{CO}_{2}$ capture unit; (2) $\mathrm{CH}_{4}$-SOFC-CLC, i.e. $\mathrm{CH}_{4}$ directly fuelled SOFC integrated with CLC; (3) SMR-SOFC, i.e. SOFC using $\mathrm{H}_{2}\left(\mathrm{H}_{2}\right.$-SOFC) generated by SMR; (4) MC-SOFC-DCFC, i.e. $\mathrm{H}_{2}$-SOFC coupled with DCFC, with $\mathrm{H}_{2}$ and $\mathrm{C}$ supplied by MC. The simplified schematics of the four fuel cell processes are described in Fig. 1. A systematic comparison of the four model processes is helpful for the selection and development of the most efficient methane (natural gas) conversion technologies.

\section{Methodology}

\subsection{Model description of SOFCs}

The SMR, MC and DCFC processes considered in this study are taken from the models reported in the literature. This section describes the detailed models of $\mathrm{CH}_{4}$-SOFC, $\mathrm{CH}_{4}$-SOFC-CLC and $\mathrm{H}_{2}$-SOFC.

Some of the SOFC models reported in the literature consider the effect of different forms of over potential on the SOFC performance, which are mainly caused by the electrochemical reaction activation, ohmic resistance and concentration
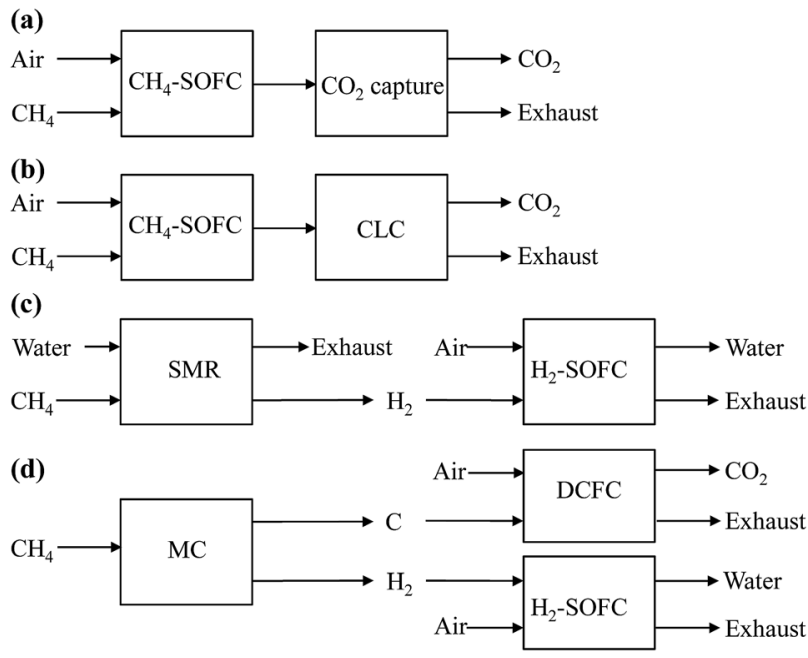

Fig. 1 Simplified schematics of fuel cell systems for power generation from methane. (a) $\mathrm{CH}_{4}$-SOFC, (b) $\mathrm{CH}_{4}$-SOFC-CLC, (c) SMR-SOFC, (d) MC-SOFC-DCFC.

depletion. ${ }^{2,8,22,23}$ The values of the over potential are determined by many factors such as temperature, material of electrolyte, and the material, size and even morphology of electrodes. When methane is directly fed into the anode chamber, steam reforming reaction takes place inside the chamber and the anode reaction is still the oxidation of hydrogen. In spite of the difference in fuels fed, all four SOFCs involve hydrogen oxidation reaction. The over potential of the oxygen reduction reaction is also common to all four SOFCs. So the over potential issues equally affect all of the four SOFCs. In this study, the ideal fuel cell model is taken and the energy loss due to over potential is neglected, which does not affect the conclusions in comparing the performance of four SOFCs.

The key components of the $\mathrm{CH}_{4}$-SOFC process developed in this investigation are a chemical equilibrium SOFC, a postburner (PB), a heat exchanger (HE), a gas turbine (GT), a condenser, an air compressor (AC), a fuel compressor (FC) and a $\mathrm{CO}_{2}$ capture unit. The detailed schematic of the system is shown in Fig. 2.

In the SOFC under operation, the molecular oxygen from preheated air (node 5) is reduced to oxygen anions at the cathode by gaining electrons supplied from an external circuit. Driven by the difference in oxygen chemical potential between the anode and cathode compartments, oxygen anions migrate through the solid electrolyte to the anode where they are consumed by oxidation of the compressed $\mathrm{CH}_{4}$ by FC. The electrons released from the electrochemical reaction flow through an external circuit to the cathode to complete the circuit. The lean fuel (node 7) and lean air (node 6) exit the cell at the operating pressure and temperature of SOFC. The $\mathrm{CO}, \mathrm{H}_{2}$ and unreacted $\mathrm{CH}_{4}$ in the lean fuel are mixed with the lean air and combusted in the PB. The high-temperature flue gas from the combustor is used to preheat the air, compressed by AC, to keep the operating temperature of the SOFC. The exhaust stream (node 9) from the HE then drives the GT to produce electricity and is cooled to $40{ }^{\circ} \mathrm{C}$ through the condenser. The 


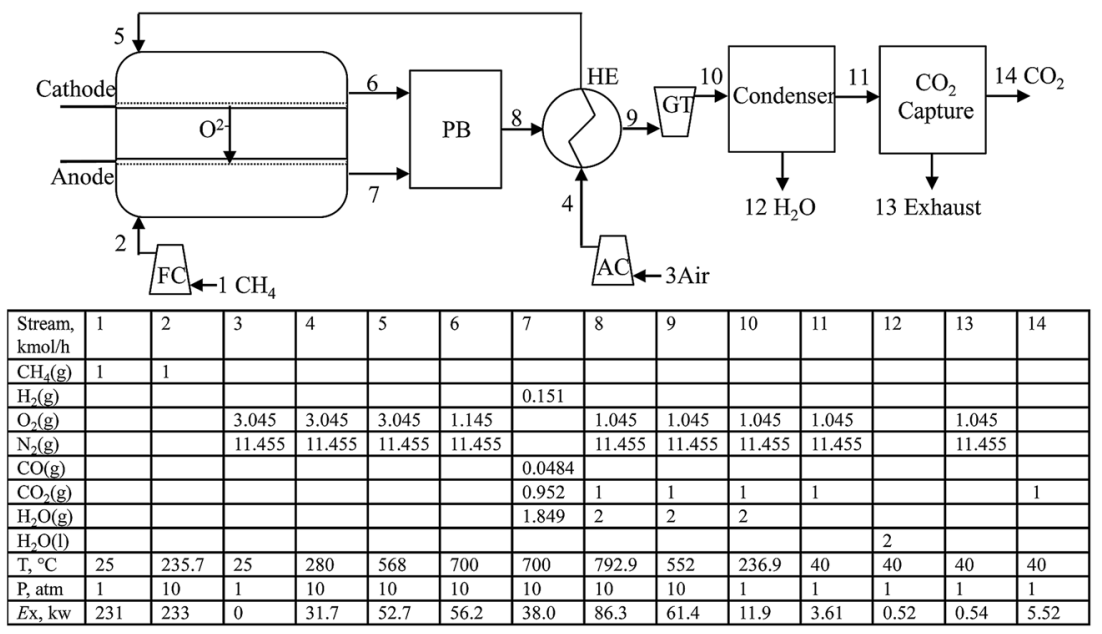

Fig. 2 The schematic of the $\mathrm{CH}_{4}$-SOFC process.

remaining gas (mostly $\mathrm{N}_{2}, \mathrm{CO}_{2}$ and $\mathrm{O}_{2}$ ) is then directed into a $\mathrm{CO}_{2}$ capture unit. In this study, consumption of $3.95 \mathrm{MJ} \mathrm{kg}^{-1}$ $\mathrm{CO}_{2}$ of heat at $220{ }^{\circ} \mathrm{C}$ and $0.32 \mathrm{MJ} \mathrm{kg}^{-1} \mathrm{CO}_{2}$ of work is assumed in the $\mathrm{CO}_{2}$ capture unit by MEA scrubbing. ${ }^{24}$

Fig. 3 shows a detailed schematic of the $\mathrm{CH}_{4}$-SOFC-CLC process. The main difference between it and $\mathrm{CH}_{4}$-SOFC depicted in Fig. 2 is that the $\mathrm{PB}$ where the direct combustion of lean fuel occurs in $\mathrm{CH}_{4}$-SOFC is replaced by a CLC unit. $\mathrm{NiO} / \mathrm{Ni}$ is used as the solid oxygen-carrier of the CLC in this model. Also, two heat exchangers (HE1 and HE2) and gas turbines (GT1 and GT2) are utilized to preheat the fresh air and recover as much heat as possible from the flue gas exiting the CLC.

The lean fuel (node 8) in this model flows into the FR and is oxidised by the NiO (node 9). The products include gas stream (node 11) containing $\mathrm{CO}_{2}$ and steam, and solid stream (node 10) containing $\mathrm{Ni}$ and a few unreacted NiO. All the solids are sent to the AR. The flue gas exiting the FR firstly drives the GT1 and then is cooled by HE1. After water condensation, an almost pure
$\mathrm{CO}_{2}$ stream obtained. The heat released from the oxidation of $\mathrm{Ni}$ by air in AR increases the temperatures of the NiO solid and the lean air (node 16). The lean air firstly preheats the fresh air to the required temperature and then drives the GT2 to produce electricity.

The detailed schematic of the $\mathrm{H}_{2}$-SOFC process is shown in Fig. 4. As $\mathrm{H}_{2}$-SOFC is fuelled by $\mathrm{H}_{2}$, the exhaust (node 10) exiting the process mainly consists of water and lean air, therefore a $\mathrm{CO}_{2}$ capture unit is not required in this model. In comparison with $\mathrm{CH}_{4}$-SOFC (Fig. 2), another difference is that the hightemperature exhaust (node 8) from the PB firstly drives a GT and then preheats the compressed air. By this arrangement, not only the compressed air is preheated to a required temperature to maintain the operating temperature of the cell, but also the exhaust gas can be used to drive a GT to produce more electricity. In comparison, the $\mathrm{CH}_{4}$-SOFC process needs to use the exhaust (node 8) from the PB to firstly preheat the compressed air (node 5), as the cell in $\mathrm{CH}_{4}$-SOFC has a higher capability of

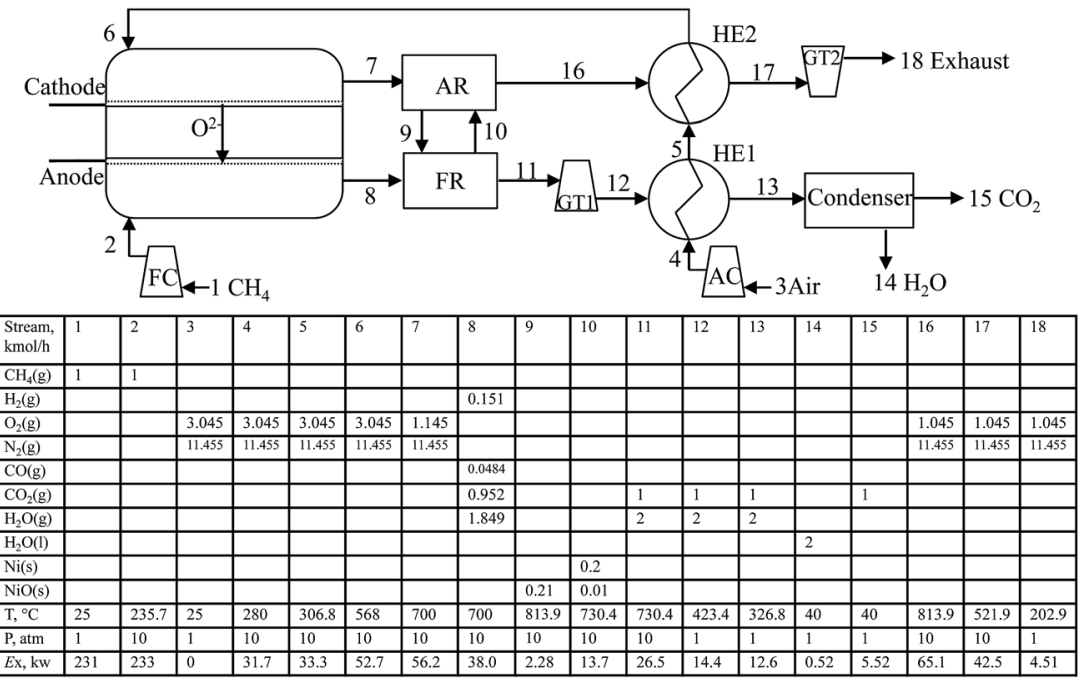

Fig. 3 The schematic of the $\mathrm{CH}_{4}$-SOFC-CLC process. 


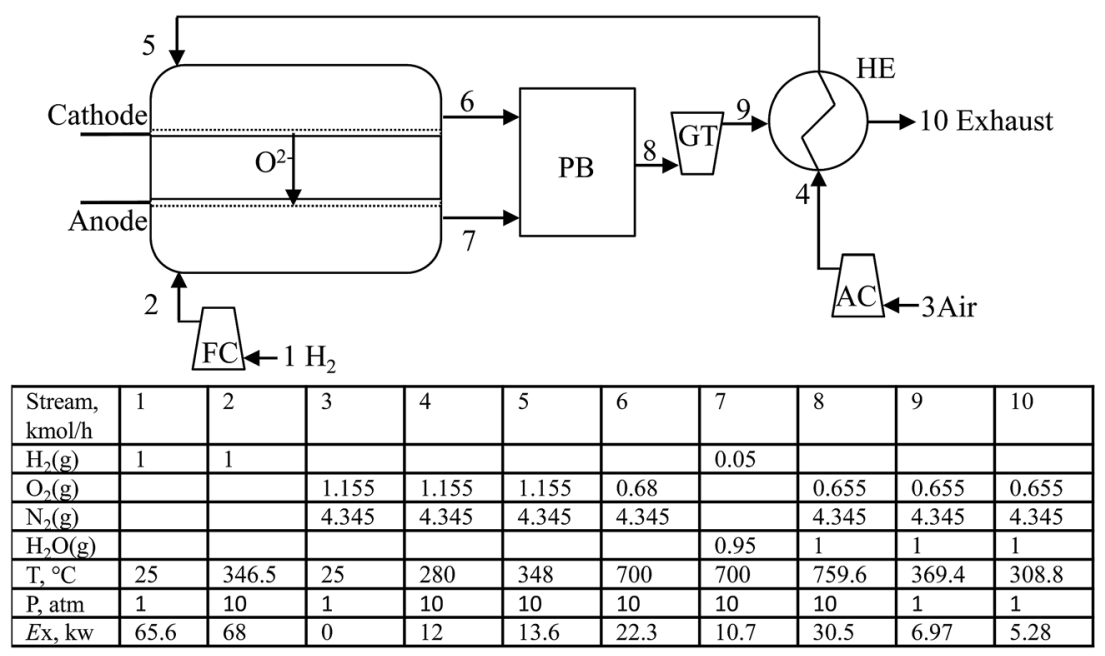

Fig. 4 The schematic of the $\mathrm{H}_{2}$-SOFC process.

producing electricity than that in $\mathrm{H}_{2}$-SOFC and the compressed air (node 5) requires to be preheated to a higher temperature to keep the operating temperature of the cell.

The maximum electrical power available from a fuel cell is determined by the Gibbs free energy difference across the electrolyte membrane, $\Delta G$. It determines the electromotive force (EMF) of the cell, $E$, through the Nernst equation. The main chemical reactions involved in $\mathrm{CH}_{4}$-SOFC are shown below, and only hydrogen combustion reaction (reaction (5)) occurs in $\mathrm{H}_{2}$-SOFC.

$$
\begin{gathered}
\mathrm{CH}_{4}+\frac{1}{2} \mathrm{O}_{2}=\mathrm{CO}+2 \mathrm{H}_{2}, \Delta H=-35.6 \mathrm{~kJ} \\
\mathrm{CO}+\frac{1}{2} \mathrm{O}_{2}=\mathrm{CO}_{2}, \Delta H=-283 \mathrm{~kJ} \\
\mathrm{H}_{2}+\frac{1}{2} \mathrm{O}_{2}=\mathrm{H}_{2} \mathrm{O}, \Delta H=-241.8 \mathrm{~kJ}
\end{gathered}
$$

Above reactions (3)-(5) consist of half cell reactions:

$$
\begin{gathered}
\frac{1}{2} \mathrm{O}_{2}+2 \mathrm{e}^{-}=\mathrm{O}_{2}^{-} \\
\mathrm{F}+\mathrm{O}_{2}^{-}=\mathrm{FO}+2 \mathrm{e}^{-}
\end{gathered}
$$

where $\mathrm{F}$ represents a molecule of fuel. Under equilibrium conditions, the concentrations of the fuel molecules are constrained by the equilibria of their conversion reactions, which can be simplified by the oxygen potential of the anode chamber:

$$
\mathrm{F}+\frac{1}{2} \mathrm{O}_{2}=\mathrm{FO}
$$

Combining reactions (7) and (8), the following reaction is obtained:

$$
\mathrm{O}_{2}^{-}=\frac{1}{2} \mathrm{O}_{2}+2 \mathrm{e}^{-}
$$

Reactions (6) and (9) consist of a concentration cell, of which the EMF is ${ }^{25}$

$$
E=(R T / 4 \mathrm{~F}) \ln \left\{P\left(\mathrm{O}_{2} \text { cathode }\right) / P\left(\mathrm{O}_{2} \text { anode }\right)\right\}
$$

The simulation of the SOFC reactions was carried out by application of Aspen Plus Software using PR-BM method. It used the built-in RGibbs modules, with an approach of Gibbs free energy minimisation. Oxygen, water, hydrogen, carbon dioxide, carbon monoxide, methane as well as pure carbon (by reaction (2)) were added manually as the possible species in $\mathrm{CH}_{4}$-SOFC and $\mathrm{CH}_{4}$-SOFC-CLC. Oxygen, water and hydrogen were chosen as the possible species in the $\mathrm{H}_{2}$-SOFC. It is found that no carbon is formed in the anode part of cells in this study.

The base-case operating parameters of the three SOFC processes are listed in Table 1. Main assumptions are considered including:

- The pressure and heat losses are ignored in all processes.

- The flow rate of fuel (methane and hydrogen) fed into each cell of three processes is set at $1 \mathrm{kmol} \mathrm{h}^{-1}$. This reference amount for calculation does not affect the calculated efficiency of the processes to be compared.

Table 1 Base-case operating parameters of three SOFC processes

\begin{tabular}{lllll}
\hline Parameter & Unit & $\mathrm{CH}_{4}$-SOFC & $\mathrm{CH}_{4}$-SOFC-CLC & $\mathrm{H}_{2}$-SO \\
\hline Fuel cell & & & & \\
Fuel type & & $\mathrm{CH}_{4}$ & $\mathrm{CH}_{4}$ & $\mathrm{H}_{2}$ \\
Fuel flow & $\mathrm{kmol} \mathrm{h}^{-1}$ & 1 & 1 & 1 \\
Air flow & $\mathrm{kmol} \mathrm{h}^{-1}$ & 14.5 & 14.5 & 5.5 \\
Temperature & ${ }^{\circ} \mathrm{C}$ & 700 & 700 & 700 \\
Pressure & $\mathrm{atm}$ & 10 & 10 & 10 \\
$\mathrm{O}_{2}$ anode,in $/$ fuel & & 1.9 & 1.9 & 0.475
\end{tabular}

Post-burner $^{a}$ Pressure atm

10

10

Air reactor ${ }^{a}$ Pressure atm $-$ 10 Fuel reactor ${ }^{a}$ Pressure atm $-$ 10

${ }^{a}$ Post-burner, air reactor and fuel reactor are operated adiabatically; the operating temperatures are determined by the heat balance of each device. 
- Air is assumed to be constituted by $21 \mathrm{vol} \% \mathrm{O}_{2}$ and $79 \mathrm{vol} \%$ $\mathrm{N}_{2}$.

- AC is assumed to be a three stage compressor. The polytropic and mechanical efficiencies for all turbines and compressors are considered as 0.86 and 0.9 , respectively.

- The minimum temperature difference in heat exchangers is considered to be is $20{ }^{\circ} \mathrm{C}$.

\subsection{Exergy analysis}

The exergy of a substance is evaluated against the environment which is assumed to be at $25{ }^{\circ} \mathrm{C}$ and $1 \mathrm{~atm}$ in this study. Three forms of exergy transfer are present in a system, namely, work interaction, heat interaction and that occurred due to material streams and detailed calculation methods of the three forms of exergy can be found elsewhere. ${ }^{26}$ Table 2 lists the standard mole chemical exergy of materials used in this study. ${ }^{26}$

The exergy destruction $\left(\mathrm{Ex}_{\mathrm{dest}}\right)$ for a steady-state system is calculated via exergy balance, defined in eqn (11). $\mathrm{Ex}_{\mathrm{dest}}$ measures the unrecoverable lost capability to do work. The lost exergy loss $\left(\mathrm{Ex}_{\mathrm{ls}}\right)$ is defined in eqn (12) as the sum of $\mathrm{Ex}_{\mathrm{dest}}$ within the system and the exergy ejected $\left(\mathrm{Ex}_{\mathrm{ej}}\right)$ in the streams which are not utilized. The unutilized streams include streams 12, 13 and 14 in $\mathrm{CH}_{4}$-SOFC, 14, 15 and 18 in $\mathrm{CH}_{4}$-SOFC-CLC, and 10 in $\mathrm{H}_{2}$-SOFC.

$$
\begin{gathered}
\mathrm{Ex}_{\mathrm{dest}}=\mathrm{Ex}_{\mathrm{in}}-\mathrm{Ex}_{\mathrm{out}} \\
\mathrm{Ex}_{\mathrm{ls}}=\mathrm{Ex}_{\mathrm{dest}}+\mathrm{Ex}_{\mathrm{ej}}
\end{gathered}
$$

The overall exergy efficiency of these SOFC processes is defined as the ratio of the produced net power work $\left(W_{\text {net }}\right)$ to the total exergy input to the system, defined in eqn (13). $W_{\text {net }}$ is the difference between the power generated from the cells and gas turbines and that consumed by the power work consumed by the compressors.

$$
\varphi_{\text {overall }}=\frac{W_{\text {net }}}{\mathrm{Ex}_{\mathrm{in}}}
$$

Exergy analysis also can be used in individual devices. The exergy efficiency $\left(\varphi_{\mathrm{k}}\right)$ of a device $\mathrm{k}$ can be defined in eqn (14).

Table 2 Standard mole chemical exergy of pure substances ${ }^{26}$

\begin{tabular}{ll}
\hline Substance & $\mathrm{Ex}_{\mathrm{ch}}, \mathrm{J} \mathrm{mol}^{-1}$ \\
\hline $\mathrm{CH}_{4}$ & 831650 \\
$\mathrm{O}_{2}$ & 3869 \\
$\mathrm{~N}_{2}$ & 584 \\
$\mathrm{CO}$ & 275100 \\
$\mathrm{CO}_{2}$ & 19870 \\
$\mathrm{H}_{2}$ & 236100 \\
$\mathrm{H}_{2} \mathrm{O}(\mathrm{g})$ & 9500 \\
$\mathrm{H}_{2} \mathrm{O}(\mathrm{l})$ & 900 \\
$\mathrm{Ni}(\mathrm{s})$ & 232700 \\
$\mathrm{NiO}(\mathrm{s})$ & 23000
\end{tabular}

$$
\varphi_{\mathrm{k}}=\frac{\sum \mathrm{Ex}_{\mathrm{out}, \mathrm{k}}}{\sum \mathrm{Ex}_{\mathrm{in}, \mathrm{k}}}
$$

For a chemical process such as cells, reactors and postburners, both physical and chemical exergy are included in the calculation of $\varphi_{\mathrm{k}}$. For pumps and compressors, only the power supplied to the devices is counted in the exergy input while the exergy increase in the stream leaving pumps and compressors is included in the exergy output. For heat exchangers, the reduction of the physical exergy of the hot streams corresponding to their temperature reduction is counted as the exergy input while the increase of the physical exergy of the cold streams corresponding to their temperature increase is considered as the exergy output, because only heat transfer is involved in the energy transformation processes.

\section{Results and discussion}

\subsection{Exergy analysis of $\mathrm{CH}_{4}-\mathrm{SOFC}, \mathrm{CH}_{4}-\mathrm{SOFC}-\mathrm{CLC}$ and $\mathrm{H}_{2}$ - SOFC}

All the cells in the three processes are assumed to be operated at $700{ }^{\circ} \mathrm{C}$ and $10 \mathrm{~atm}$. In general, the oxygen content in the cathode compartment of a SOFC is lower than $21 \%$. However, if the air amount entering the cathode compartment carries far larger amount of $\mathrm{O}_{2}$ than that passing through the solid electrolyte, assuming a constant partial pressure of $\mathrm{O}_{2}$ $\left(\mathrm{PO}_{2}=2.1 \mathrm{~atm}\right)$ in the cathode compartment does not cause significant deviation in the calculated power output.

The amount of $\mathrm{O}_{2}$ passing through the solid electrolyte of a SOFC for per mole of fuel has a significant impact on the equilibrium composition of the lean fuel in the anode compartment and the corresponding capability of producing electricity of the SOFC. Fig. 5(a) presents the effect of the molar ratio of the oxygen passing through the solid electrolyte to the fuel $\left(\mathrm{CH}_{4}\right)$ flowing into the anode compartment of the $\mathrm{CH}_{4}$-SOFC $\left(\mathrm{O}_{2}\right.$ anode,in $\left./ \mathrm{CH}_{4}\right)$ on the equilibrium $\mathrm{O}_{2}$ partial pressure of the lean fuel leaving the anode compartment $\left(P\left(\mathrm{O}_{2}\right.\right.$ anode $\left.)\right)$. When the $\mathrm{O}_{2}$ anode,in $/ \mathrm{CH}_{4}$ ratio is below 1.7, increasing the $\mathrm{O}_{2}$ anode,in $/ \mathrm{CH}_{4}$ has little effect on the $P\left(\mathrm{O}_{2}\right.$ anode $)$, and so on EMF of the cell, but results in an increase of the electric charge transferred by the cell, and so the power output increases nearly linearly. As $\mathrm{O}_{2}$ anode, in $/ \mathrm{CH}_{4}$ ratio approaches 2, the combustion of $\mathrm{CH}_{4}$ approaches completion. The $P\left(\mathrm{O}_{2}\right.$ anode $)$ increases sharply, causing the power output reaching a peak at about $\mathrm{O}_{2}$ anode,in $/ \mathrm{CH}_{4}=1.9$. Beyond this range, the power output sharply decreases due to the decrease of the EMF corresponding to the increase of the oxygen content in the lean fuel. As shown in Fig. 5(b), similar trends are there in the changes of the $P\left(\mathrm{O}_{2}\right.$ anode $)$ and the power output from a $\mathrm{H}_{2}$-SOFC operated at the same conditions as the $\mathrm{CH}_{4}$-SOFC. The combustion of $\mathrm{H}_{2}$ approaches completion and the $P\left(\mathrm{O}_{2}\right.$ anode $)$ increases sharply, when the $\mathrm{O}_{2}$ anode,in $/ \mathrm{H}_{2}$ approaches 0.5 corresponding to the stoichiometry of reaction (5). The peak power output appears at $\mathrm{O}_{2}$ anode,in $/ \mathrm{CH}_{4}$ ratio about 0.475 . 

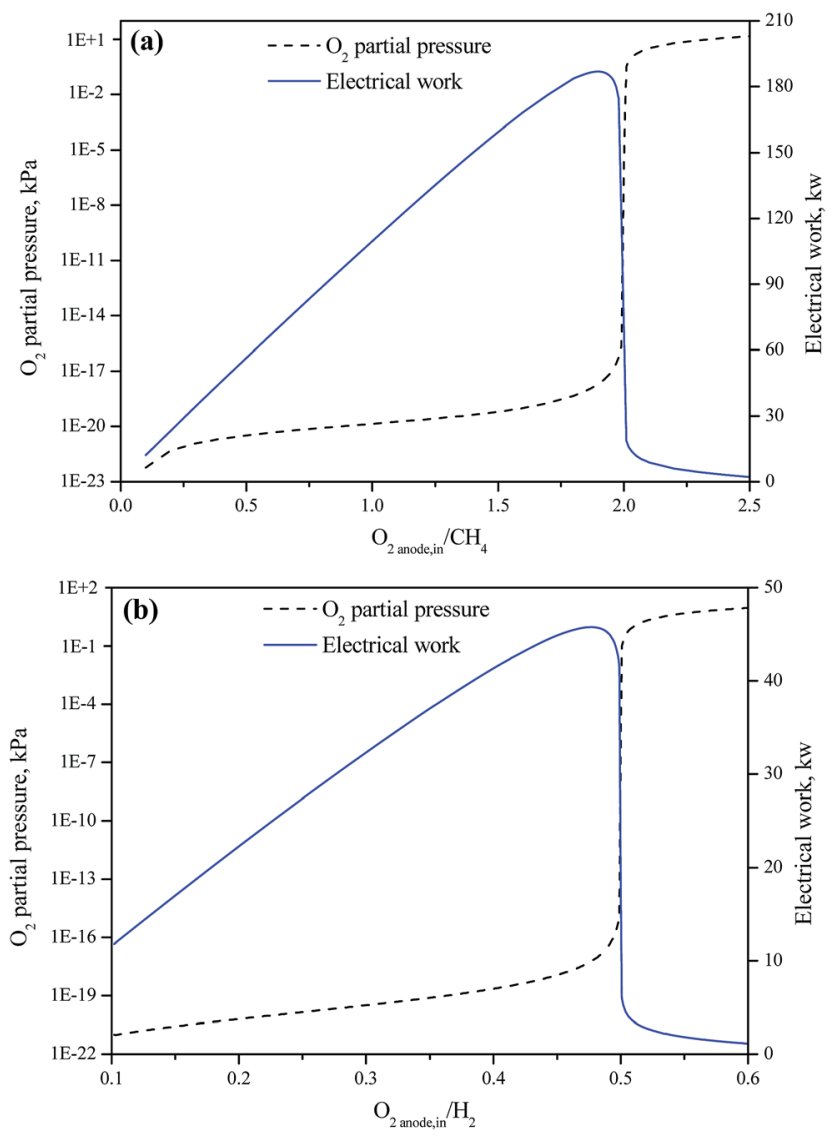

Fig. 5 The effect of the molar ratio of $\mathrm{O}_{2}$ and fuel flowing into the anode compartment of SOFC on the equilibrium $\mathrm{O}_{2}$ partial pressure of lean fuel leaving the anode compartment and the electrical power produced by (a) $\mathrm{CH}_{4}$-SOFC and (b) $\mathrm{H}_{2}$-SOFC, both operated at $700{ }^{\circ} \mathrm{C}$ and $10 \mathrm{~atm}$ and with a constant $\mathrm{O}_{2}$ content at $21 \%$ in the cathode compartment.

In this work, the exergy analysis of $\mathrm{CH}_{4}$-SOFC and $\mathrm{CH}_{4}$-SOFC-CLC systems is carried out at $\mathrm{O}_{2}$ anode,in $/ \mathrm{CH}_{4}=1.9$; while for $\mathrm{H}_{2}$-SOFC system, it is carried out at $\mathrm{O}_{2}$ anode, in $/ \mathrm{H}_{2}=0.475$.

3.1.1 The performance of three SOFC systems. When the ratio of oxygen to fuel (methane or hydrogen) passing through the solid electrolyte is fixed, increasing the amount of air flowing into cathode compartment results in more electrical power generation of the system from the cell due to the increased oxygen partial pressure in the cathode compartment $\left(P\left(\mathrm{O}_{2}\right.\right.$ cathode $\left.)\right)$, however, the consumption of electrical power to compress the air also increases. Consequently, the overall exergy efficiency reaches the maximum when $14.5 \mathrm{kmol} \mathrm{h}^{-1}$ air flows into $\mathrm{CH}_{4}$-SOFC and $\mathrm{CH}_{4}$-SOFC-CLC, and $4.8 \mathrm{kmol} \mathrm{h}^{-1}$ air into $\mathrm{H}_{2}$-SOFC. More detailed discussion on the effect of air flow is conducted in Section 3.1.2.

Table 3 presents the exergy balances and exergy efficiencies of $\mathrm{CH}_{4}$-SOFC, $\mathrm{CH}_{4}$-SOFC-CLC and $\mathrm{H}_{2}$-SOFC operating with the base-case parameters shown in Table 1. For the $\mathrm{CH}_{4}$-SOFC-CLC and $\mathrm{H}_{2}$-SOFC processes, the exergy input is only from the fuel. The $\mathrm{CO}_{2}$ separation unit of the $\mathrm{CH}_{4}$-SOFC process to capture the $\mathrm{CO}_{2}$ generated by the combustion of $\mathrm{CH}_{4}$ brings about extra
Table 3 Exergy balances and exergy efficiencies of $\mathrm{CH}_{4}-\mathrm{SOFC}$, $\mathrm{CH}_{4}$-SOFC-CLC and $\mathrm{H}_{2}$-SOFC

\begin{tabular}{|c|c|c|c|c|c|c|}
\hline & \multicolumn{2}{|c|}{$\mathrm{CH}_{4}$-SOFC } & \multicolumn{2}{|c|}{$\begin{array}{l}\mathrm{CH}_{4} \text {-SOFC- } \\
\mathrm{CLC}\end{array}$} & \multicolumn{2}{|c|}{$\mathrm{H}_{2}$-SOFC } \\
\hline & $\mathrm{kW}$ & $\%$ & $\mathrm{~kW}$ & $\%$ & $\mathrm{~kW}$ & $\%$ \\
\hline Exergy input & 254 & 100 & 231 & 100 & 65.6 & 100 \\
\hline $\mathrm{Ex}_{\mathrm{CH}_{4}}$ & 231 & 90.9 & 231 & 100 & - & - \\
\hline $\mathrm{Ex}_{\mathrm{H}_{2}}$ & - & - & - & - & 65.6 & 100 \\
\hline$W_{\text {compressors }}{ }^{a}$ & $(36.4)$ & - & $(36.4)$ & - & $(15.6)$ & - \\
\hline $\mathrm{Ex}_{\mathrm{CO}_{2} \text { capture }}$ & 23 & 9.10 & - & - & - & - \\
\hline Exergy output & 197 & 77.5 & 201 & 87.2 & 56.2 & 85.6 \\
\hline$W_{\text {cell }}$ & 183 & 72.1 & 183 & 79.3 & 45.3 & 69.1 \\
\hline$W_{\mathrm{GT}}^{\prime}{ }^{b}$ & 7.06 & 2.78 & 7.61 & 3.3 & 5.59 & 8.53 \\
\hline $\mathrm{Ex}_{\mathrm{ej}}$ & 6.58 & 2.59 & 10.6 & 4.57 & 5.28 & 8.05 \\
\hline $\mathrm{Ex}_{\mathrm{ch}, \mathrm{CO}_{2}}{ }^{c}$ & $(5.52)$ & - & $(5.52)$ & - & - & - \\
\hline Destroyed exergy & 57.2 & 22.5 & 29.6 & 12.8 & 9.42 & 14.4 \\
\hline Lost exergy & 63.8 & 25.1 & 40.2 & 17.4 & 14.7 & 22.4 \\
\hline Exergy efficiency & & 74.9 & & 82.6 & & 77.6 \\
\hline
\end{tabular}

${ }^{a}$ Energy consumed by compressors (data in brackets) is considered from expanding gas turbines and so not counted in the exergy input.

${ }^{b}$ Net power output of gas turbines is after subtracting that consumed by compressors. ${ }^{c} \mathrm{Ex}_{\mathrm{ch}, \mathrm{CO}_{2}}$ is counted in the $\mathrm{Ex}_{\mathrm{ej}}$ and so not repeatedly counted in the exergy output.

consumption of exergy, accounting for $9.1 \%$ of the total exergy input in the process.

The exergy output of the three processes is mainly contributed by the power produced by each cell $\left(W_{\text {cell }}\right)$; the major lost exergy is the destroyed exergy owing to the irreversibility in the processes. The $\mathrm{CH}_{4}$-SOFC-CLC process obtains the highest exergy efficiency $(82.6 \%)$, followed by $\mathrm{H}_{2}$-SOFC $(77.6 \%)$. The lowest exergy efficiency occurs in $\mathrm{CH}_{4}$-SOFC, $74.9 \%$. It is noted that without capturing the $\mathrm{CO}_{2}$ in the flue gas the exergy efficiency of $\mathrm{CH}_{4}$-SOFC can reach $82.4 \%$, which is close to that of $\mathrm{CH}_{4}$-SOFC-CLC. It is also noted that the exergy efficiencies of $\mathrm{CH}_{4}$-SOFC (74.9\%) and $\mathrm{H}_{2}$-SOFC $(77.6 \%)$ are higher than those given in some other thermodynamic SOFC analysis papers, which is reasonable since the ideal fuel cell model is assumed and the exergy destruction due to over potential is neglected in this work. The adoption of gas turbines to recover the pressure energy of the off gases for power generation contributes to the high efficiency of the processes.

Over potential is a common issue related to the characteristics of electrochemical reactions and detailed reaction conditions, such as temperature, the material of electrolyte, the material, size and even morphology of electrodes, the current density on the electrodes for a given electrode reaction, etc. Fig. 6 shows the effect of over potential on the exergy efficiencies of the three SOFC processes. The exergy efficiencies of all of the processes decreased greatly with the increase of over potential. Reducing over potential is one of the key engineering technologies to improve the energy conversion efficiency of SOFC systems.

To further understand the exergy destruction in the three SOFC processes, the exergy analysis of each device in the processes is implemented, and the results are listed in Table 4. 


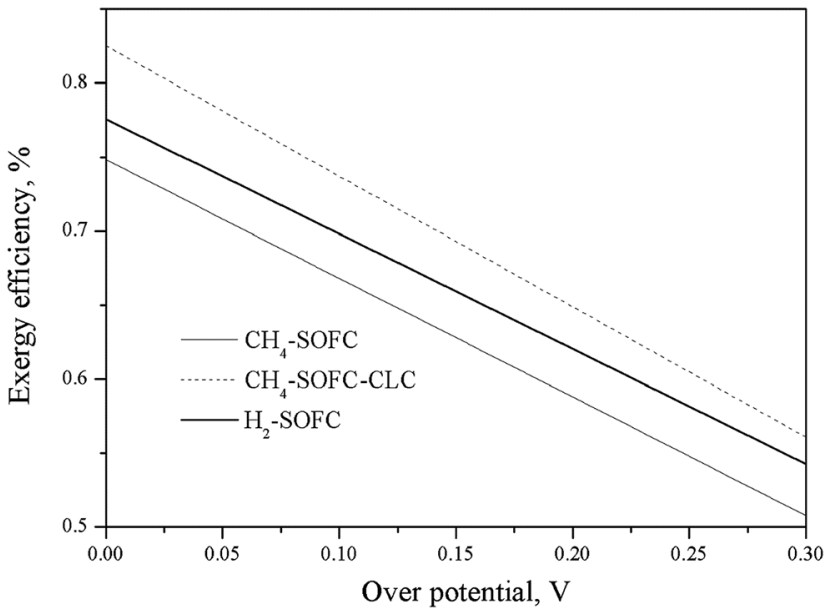

Fig. 6 Effect of over potential on the exergy efficiencies of $\mathrm{CH}_{4}$-SOFC, $\mathrm{CH}_{4}$-SOFC-CLC and $\mathrm{H}_{2}$-SOFC.

The $\mathrm{CO}_{2}$ capture unit is the most exergy destruction intensive device in the $\mathrm{CH}_{4}$-SOFC process. This unit has the lowest exergy efficiency (22.8\%), destroying $35.9 \%$ of the total $\mathrm{Ex}_{\mathrm{dest}}$ in the process. The major exergy destruction is resulted from the unavoidable heat exergy required for the regeneration of the MEA after $\mathrm{CO}_{2}$ absorption. The $\mathrm{CO}_{2}$ capture unit has a high energy penalty, resulting in a large decrease $(7.5 \%)$ in the overall exergy efficiency in $\mathrm{CH}_{4}$-SOFC, as shown in Table 3.

The condenser in the $\mathrm{CH}_{4}$-SOFC process also has a very low exergy efficiency of $34.8 \%$, mainly because the heat is released from condenser to the atmosphere and not utilized. In comparison, the $\varphi_{\text {condenser }}$ in $\mathrm{CH}_{4}$-SOFC-CLC is slightly higher, $48.0 \%$. This is because the heat wasted in the condenser in the latter process is less than that in the former.

As the kernel device with the purpose of producing electricity from fuel, the cells account for $14.8 \%$ of the total $\mathrm{Ex}_{\text {dest }}$ in $\mathrm{CH}_{4}$-SOFC, $28.5 \%$ in $\mathrm{CH}_{4}$-SOFC-CLC and $35.5 \%$ in $\mathrm{H}_{2}$-SOFC. The $\varphi_{\text {cell }}$ in $\mathrm{CH}_{4}$-SOFC and $\mathrm{CH}_{4}$-SOFC-CLC reaches $97.0 \%$ and is slightly higher than that of $\mathrm{H}_{2}$-SOFC (95.9\%), which means that methane fuelled SOFC has higher capacity of electricity production than hydrogen fuelled SOFC. The exergy destruction happened in cells is mostly due to mixing of fuels in the anode compartment, and heating fuels and air streams to the operating temperature. The high exergy efficiencies (over $95 \%$ ) of the three cells are because the cell reactions are assumed at equilibrium. To reduce the exergy destruction in the cells, the fuels $\left(\mathrm{CH}_{4}\right.$ and $\left.\mathrm{H}_{2}\right)$ in the three processes can be preheated to decrease the exergy destruction caused by the temperature difference between the fuels and other gas species in the cells.

The post-burner and CLC unit are also significant exergy destroyers. The exergy destruction in the devices is mainly due to the large amount of entropy produced during the oxidation of fuels in the post-burner or metallic Ni in the CLC unit. It can be seen that although the mass and energy balances between the post-burner in $\mathrm{CH}_{4}$-SOFC and the CLC unit in $\mathrm{CH}_{4}$-SOFC-CLC are completely same, the $\varphi_{\mathrm{CLC}}$ unit in $\mathrm{CH}_{4}$-SOFC-CLC $(97.3 \%)$ is $5.6 \%$ higher than $\varphi_{\text {post-burner }}(91.7 \%)$ in $\mathrm{CH}_{4}$-SOFC. This is mainly because the mixing of lean fuel and lean air in the postburner also leads to unavoidable exergy destruction as the mixing process is irreversible. The destroyed exergy in the lean

Table 4 Exergy destruction in individual devices of three SOFC processes

\begin{tabular}{|c|c|c|c|c|c|c|c|c|c|}
\hline & \multicolumn{3}{|c|}{$\mathrm{CH}_{4}$-SOFC } & \multicolumn{3}{|c|}{$\mathrm{CH}_{4}$-SOFC-CLC } & \multicolumn{3}{|c|}{$\underline{\mathrm{H}_{2}-\mathrm{SOFC}}$} \\
\hline & $\begin{array}{l}E_{x_{\text {dest }}} \\
(\mathrm{kW})\end{array}$ & $\begin{array}{l}\% \text { of total } \\
\operatorname{Ex}_{\text {dest }}(\%)\end{array}$ & $\begin{array}{l}\text { Device } \\
\varphi_{\mathrm{k}}(\%)\end{array}$ & $\begin{array}{l}\text { Ex }_{\text {dest }} \\
(\mathrm{kW})\end{array}$ & $\begin{array}{l}\% \text { of total } \\
\operatorname{Ex}_{\text {dest }}(\%)\end{array}$ & $\begin{array}{l}\text { Device } \varphi_{\mathrm{k}} \\
(\%)\end{array}$ & $\begin{array}{l}\text { Ex }_{\text {dest }} \\
(k W)\end{array}$ & $\begin{array}{l}\% \text { of total } \\
\mathrm{Ex}_{\text {dest }}(\%)\end{array}$ & $\begin{array}{l}\text { Device } \varphi_{\mathrm{k}} \\
(\%)\end{array}$ \\
\hline Cell & 8.47 & 14.8 & 97.0 & 8.47 & 28.5 & 97.0 & 3.34 & 35.5 & 95.9 \\
\hline Post-burner & 7.86 & 13.8 & 91.7 & - & - & - & 2.53 & 26.9 & 92.3 \\
\hline CLC unit & - & - & - & 2.59 & 8.72 & 97.3 & - & - & - \\
\hline $\mathrm{CO}_{2}$ capture & 20.5 & 35.9 & 22.8 & - & - & - & - & - & - \\
\hline \multicolumn{10}{|l|}{ Compressors } \\
\hline $\mathrm{AC}$ & 2.32 & 4.06 & 93.2 & 2.32 & 7.82 & 93.2 & 0.88 & 9.34 & 93.2 \\
\hline FC & 0.24 & 0.42 & 90.2 & 0.24 & 0.81 & 90.2 & 0.24 & 2.58 & 90.9 \\
\hline \multicolumn{10}{|l|}{ Heat exchangers } \\
\hline $\mathrm{HE}$ & 3.93 & 6.87 & 82.9 & - & - & - & 0.08 & 0.87 & 95.9 \\
\hline HE1 & - & - & - & 0.24 & 0.82 & 87.8 & - & - & - \\
\hline $\mathrm{HE} 2$ & - & - & - & 3.17 & 10.7 & 84.6 & - & - & - \\
\hline Condenser & 7.72 & 13.5 & 34.8 & 6.53 & 22.0 & 48.0 & - & - & - \\
\hline Total destroyed exergy & 57.2 & 100 & & 29.6 & 100 & & 9.42 & 100 & \\
\hline
\end{tabular}


fuel/air mixing is already minimized in the post-burners as the same temperatures of lean air and lean mixer do not result in further exergy destruction due to heat transfer. It is noted that the exergy efficiencies of the post-burners and CLC unit in this study are higher than those of the combustors in some previous publications. ${ }^{4,27}$ This is mainly because the high extent of reactions occurring in cells resulted in very limited amount of combustible gases $\left(\mathrm{H}_{2}, \mathrm{CO}\right.$ and $\left.\mathrm{CH}_{4}\right)$ in the lean fuel streams and the amount of air flowing into the post-burner and CLC is much higher than the stoichiometric value for combustion.

In a heat exchanger, the heat transfer across a finite temperature difference contribute to the inherent exergy destruction. In this study, the $\mathrm{HE}$ in $\mathrm{H}_{2}$-SOFC has the highest exergy efficiency (95.9\%) due to its relatively small temperature difference between hot and cold streams. Reducing the temperature difference can be an option of decreasing the exergy destruction in a heat exchanger, although practically it could increase the size and the corresponding capital cost of the heat exchanger.

3.1.2 Effects of operating parameters on the SOFC performance. This section examines the effects of the cell operating temperature, pressure and air flow on the overall exergy efficiency and exergy flows in the three SOFC processes. As the trends of the effects of these parameters are found similar in the three SOFC processes, only the parametric study results in the $\mathrm{CH}_{4}$-SOFC process are presented in this section. The results are calculated by varying one parameter while maintaining all other parameters constant at their base-case values.

Fig. 7(a) shows the effect of the cell operating temperature on the overall exergy efficiency and the global exergy flows of $\mathrm{CH}_{4}$-SOFC. As the operating temperature increases from 400 to $1000{ }^{\circ} \mathrm{C}$, the overall exergy efficiency and the net amount of electricity produced in the process decrease from $79.1 \%$ to $67.9 \%$ and from $201 \mathrm{~kW}$ to $172 \mathrm{~kW}$, respectively. Since the oxidation reactions occurring in the cell are exothermic, a higher temperature decreases the equilibrium constant of reactions and so shifts the equilibrium position towards the reactants. As a result, the equilibrium $P\left(\mathrm{O}_{2}\right.$ anode $)$ increases quickly and decreases the electrical work produced by the cell consequently. Increasing the temperature of flue gas from PB can produce more electricity by GT, but it is not enough to compensate the loss of electricity produced by the cell. Therefore, the total amount of net electricity produced in the process decreases with increasing the cell operating temperature, as shown in Fig. 6(a). There is also an increase in the amount of destroyed exergy with increasing the cell operating temperature.

The effect of cell temperature on the destroyed exergy in each device in $\mathrm{CH}_{4}$-SOFC was shown in Fig. 7 (b). The amount of destroyed exergy in $\mathrm{CO}_{2}$ capture and compressors remains constant. The increase in the total destroyed exergy in the whole process was mainly attributed to the condenser, cell and HE. Among the three devices, the destroyed exergy in the condenser increases at the highest rate. This is mainly because a higher temperature is reached by the exhaust steam (node 10 in Fig. 2) and more heat is wasted in the condenser during cooling. Also, a higher cell temperature also increases the heat transfer occurred in the cell and HE, which consequently leads to more exergy destruction in these two devices.
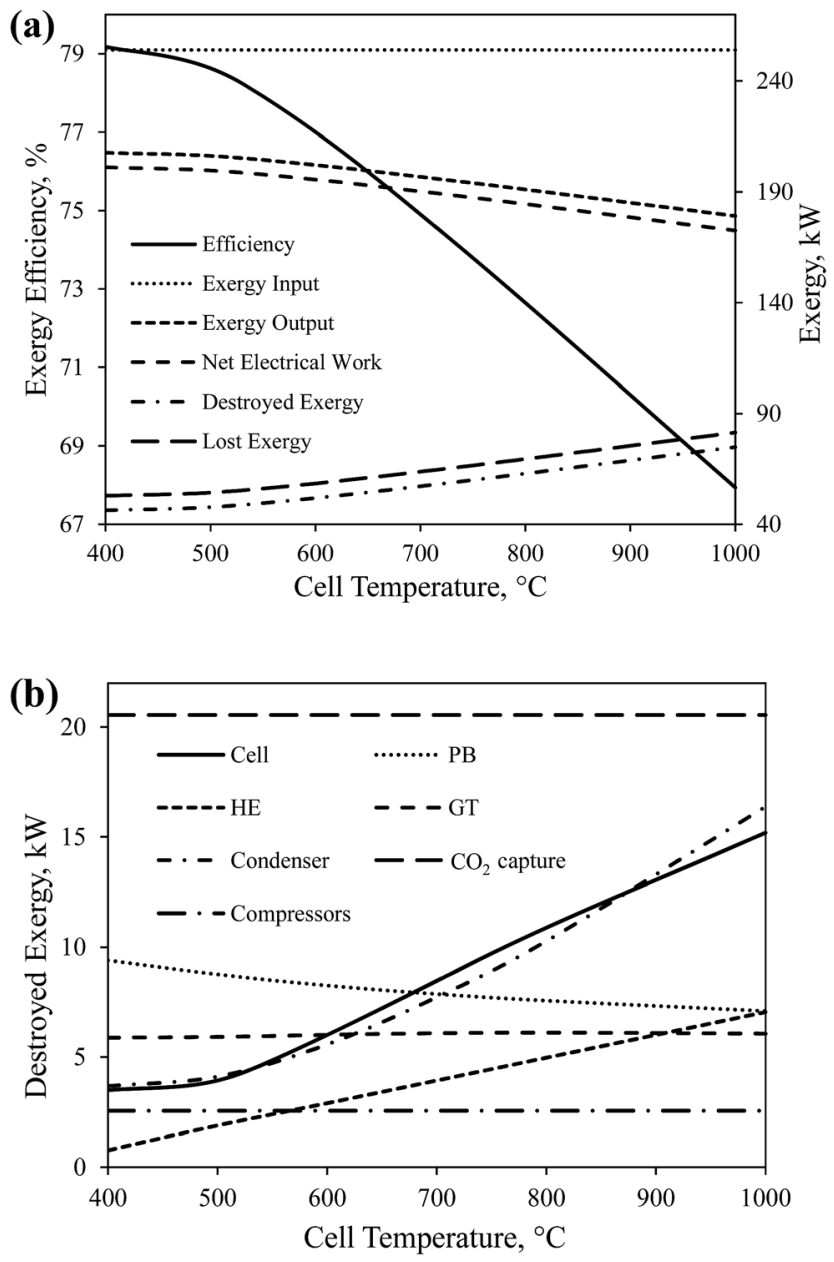

Fig. 7 The effect of cell operating temperature on (a) the overall exergy efficiency and global exergy flows of $\mathrm{CH}_{4}$-SOFC, and (b) the destroyed exergy in each device.

The data presented in Fig. 7(a) and (b) indicate that decreasing the working temperature of the SOFCs increases the exergy efficiency of the system, which demonstrates the necessity to develop novel solid electrolyte materials capable of delivering oxygen at lower temperatures.

Fig. 8(a) shows the effect of the cell operating pressure on the overall exergy efficiency and the global exergy flows of $\mathrm{CH}_{4}$-SOFC. The overall exergy efficiency increases gradually from $71.0 \%$ to $75.3 \%$ with increasing the cell pressure from 2 to $20 \mathrm{~atm}$. This is mainly resulted from the increase in net amount of electricity produced in the process from $180 \mathrm{~kW}$ to $191 \mathrm{~kW}$ and the corresponding decrease in the amount of destroyed exergy from $67.2 \mathrm{~kW}$ to $56.2 \mathrm{~kW}$. Increasing the cell pressure increases the electrical work produced in both the cell and GT. When the operating pressure is above $10 \mathrm{~atm}$, the increase in the overall exergy efficiency with increasing pressure becomes less significant. This is because above 10 atm the net amount of electricity produced in the process increases at a lower rate, while the consumption rate of electricity in compressors increases linearly.

The effect of cell pressure on the destroyed exergy in each device was shown in Fig. 8(b). The decrease in the total 

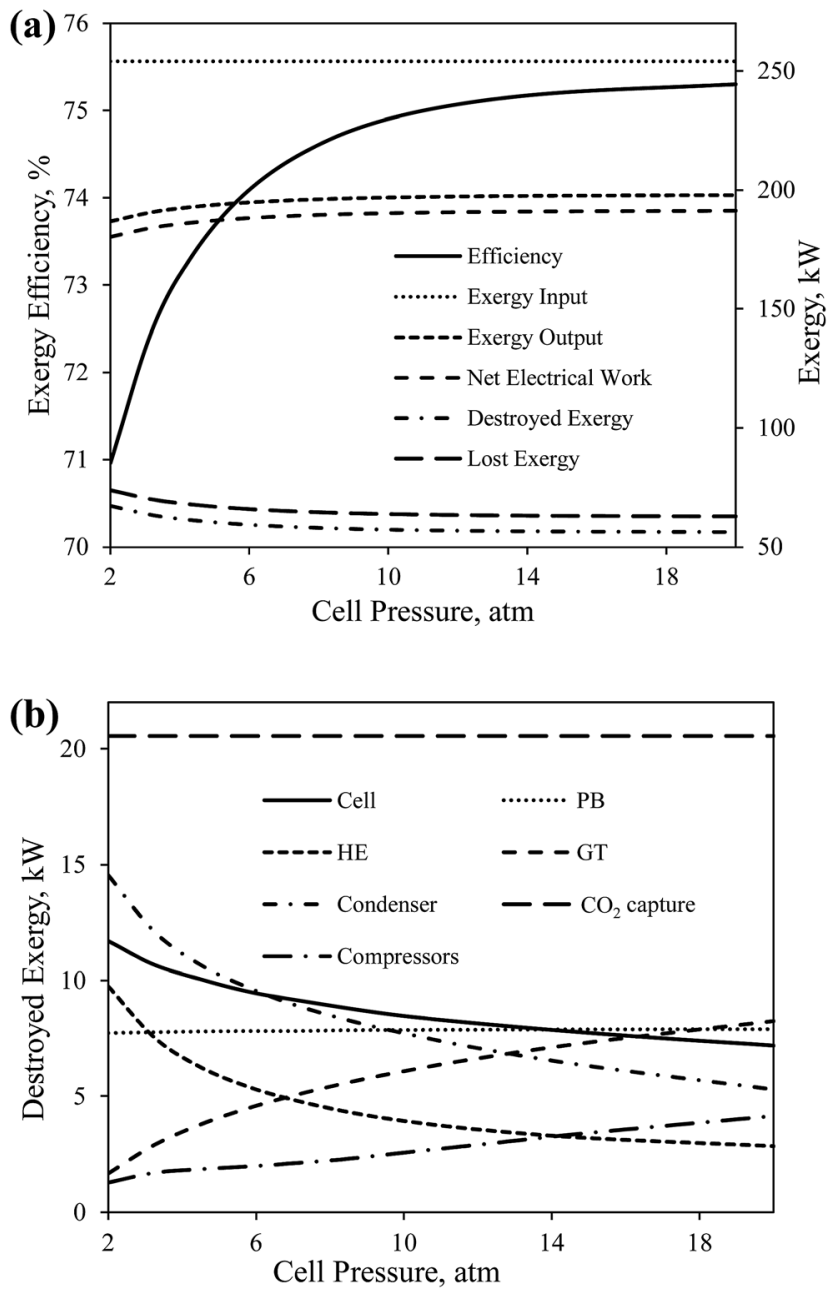

Fig. 8 The effect of cell operating pressure on (a) the overall exergy efficiency and global exergy flows of $\mathrm{CH}_{4}$-SOFC, and (b) the destroyed exergy in each device in $\mathrm{CH}_{4}$-SOFC.

destroyed exergy of the process is mostly contributed to the cell, $\mathrm{HE}$ and condenser. The decrease in the heat duties in the condenser decreases the destroyed exergy in the device. Also, the temperature of the preheated air (node 5 in Fig. 2) increases with the increase in the cell pressure. This decreases the temperature difference of heat transfer in the HE and cell, which correspondingly results in less exergy destruction in the two devices.

Fig. 9(a) and (b) show the effect of the air flow rate into the cathode compartment on the overall exergy efficiency and the global exergy flows of $\mathrm{CH}_{4}$-SOFC. The exergy efficiency reaches the maximum of $74.9 \%$ when the air flow rate is $14.5 \mathrm{kmol} \mathrm{h}^{-1}$. The total amount of electricity produced by the cell $\left(W_{\text {cell }}\right)$ and GT $\left(W_{\mathrm{GT}}\right)$ increases gradually with increasing the air flow rate from 10 to $30 \mathrm{kmol} \mathrm{h}^{-1}$. The growth of the produced electricity by the cell slows down when the air flow rate exceeds about $14 \mathrm{kmol} \mathrm{h}^{-1}$, while the consumed electricity in compressors ( $W_{\text {compressors }}$ ) increases with increasing the air flow rate at a higher rate. Therefore, there is a trade-off between the increased electrical work produced by the cell and GT and the consumed work by compressors, which forms the peak total net electricity produced
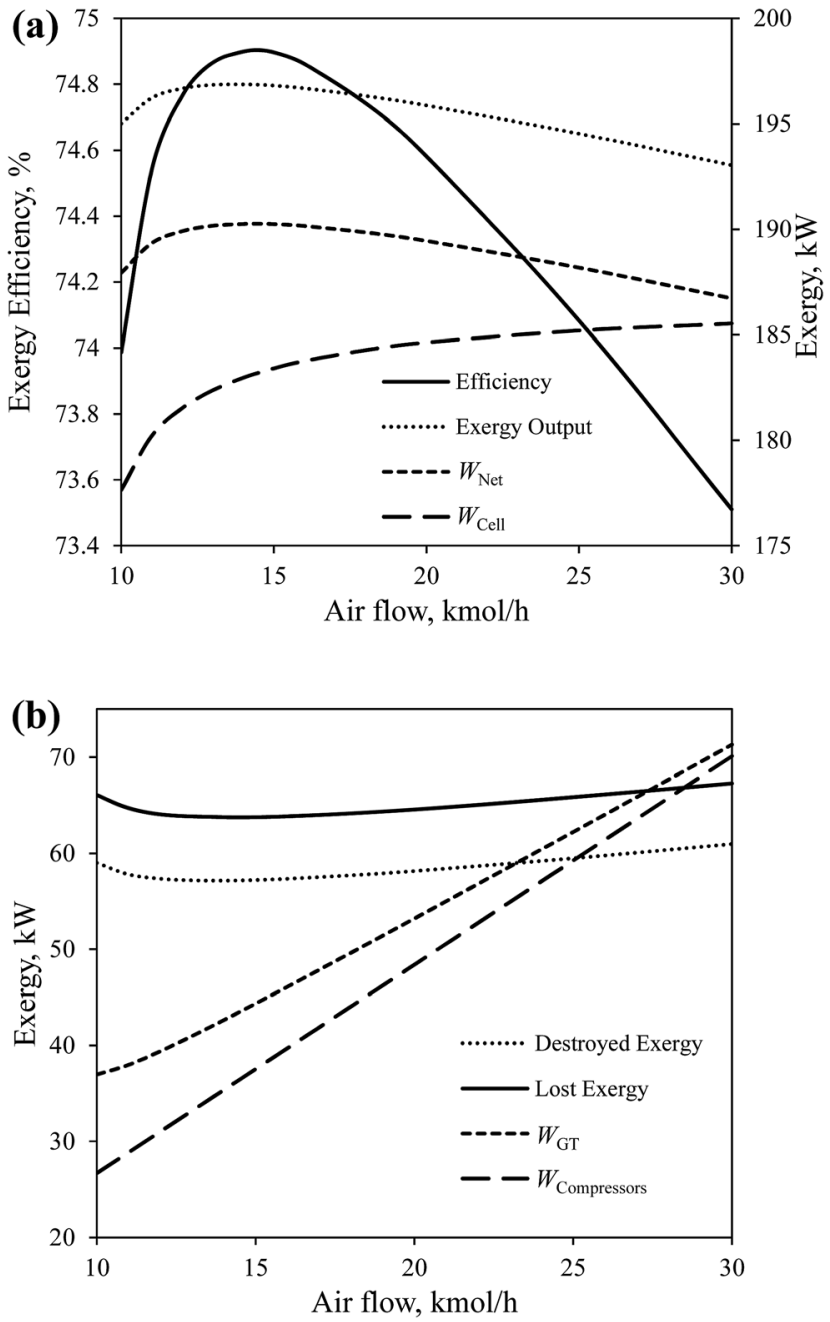

Fig. 9 The effect of the air flow rate on the overall exergy efficiency and global exergy flows of $\mathrm{CH}_{4}$-SOFC.

( $\left.W_{\text {cell }}\right)$ when the air flow rate is $14.5 \mathrm{kmol} \mathrm{h}^{-1}$. Also, the destroyed exergy reaches the lowest at the same air flow rate.

The effect of air flow rate on the destroyed exergy in each device in $\mathrm{CH}_{4}$-SOFC is shown in Fig. 10. Along with increasing the air flow rate, the temperature of preheated air gradually decreases to keep the operating temperature of the cell constant. This decreases the temperature difference of the heat transfer and the destroyed exergy in the cell although increases the heat duty of the HE, leading to more destroyed exergy in the HE. A higher air flow rate also increases the produced electricity and unavoidably increases the destroyed exergy in the GT. Furthermore, an increase in the net electricity produced in the whole process results in less energy carried by the exhaust stream (node 10 in Fig. 2), which correspondingly decreases the destroyed exergy in the condenser.

\subsection{Comparison of the four SOFC processes using $\mathrm{CH}_{4}$ as the original fuel}

To feed a $\mathrm{H}_{2}$ fuelled SOFC system, $\mathrm{H}_{2}$ can be produced from hydrocarbons particularly natural gas, and the loss of energy 


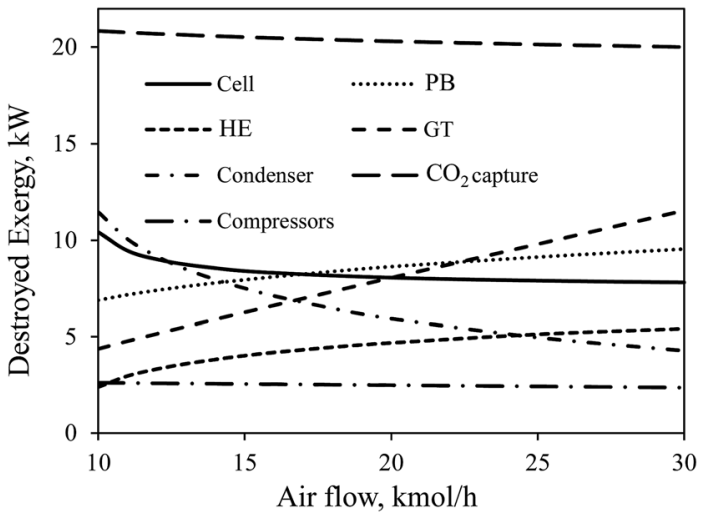

Fig. 10 The effect of the air flow rate on the destroyed exergy in each device in $\mathrm{CH}_{4}$-SOFC.

unavoidably occurs during a $\mathrm{H}_{2}$ production process. It is necessary to compare the exergy utilization of the integrated $\mathrm{H}_{2}$-SOFC process starting with $\mathrm{CH}_{4}$ fuel with other fuel cell processes directly using $\mathrm{CH}_{4}$ as fuel (as presented in Fig. 1).

The process simulation and thermodynamics of SMR have been thoroughly studied. The exergy efficiency of SMR, $\varphi_{\mathrm{SMR}}$, is defined as the ratio of exergy in hydrogen product to the total exergy input to the system. A summary of the exergy efficiencies of SMR systems reported in literature has been made previously. ${ }^{9}$ The average value of the exergy efficiency of these SMR systems is $70.1 \%$ which is used in this work.

Muradov $^{28}$ introduced a circulating fluidized bed reactor for $\mathrm{H}_{2}$ production by a $\mathrm{MC}$ process which is performed at $850-950{ }^{\circ} \mathrm{C}$ and $10-20 \mathrm{~atm}$. The required heat for $\mathrm{MC}$ can be produced by the combustion of additional methane or nonpermeate gas. The exergy efficiency $\varphi_{\mathrm{MC}}$ is defined as the ratio of exergy in the produced hydrogen and carbon to the total exergy input to the system. In light of Muradov's model, we proposed a novel MC process integrated with a CLC. In this MC process, a CLC unit is employed to supply heat to endothermic methane cracking reaction and $\mathrm{CO}_{2}$ capture simultaneously. ${ }^{9}$ The performance of this MC process is evaluated using exergy analysis and a high exergy efficiency of $91 \%$ is reached. The novel MC model ${ }^{9}$ is used in this work.

Direct carbon fuel cell (DCFC) is the only fuel cell capable of converting solid carbon into electricity without a reforming process. In comparison with $\mathrm{H}_{2}$-based fuel cells, DCFC has the great thermodynamic advantage of a near-zero entropy change at a high temperature. Even under practical conditions, a efficiency of $80 \%$ can be reached in a DCFC system. ${ }^{29,30}$

Fig. 11 presents the simplified exergy flow diagrams of the four SOFC processes using $\mathrm{CH}_{4}$ as original fuel. In general, $\mathrm{CH}_{4}$-SOFC and $\mathrm{CH}_{4}$-SOFC-CLC processes which directly use $\mathrm{CH}_{4}$ as the fuel of cells have higher exergy efficiencies than SMR-SOFC and MC-SOFC-DCFC, as a large amount of exergy is destroyed in the $\mathrm{H}_{2}$ production processes. $\mathrm{CH}_{4}$-SOFC-CLC obtains the highest exergy efficiency among the four processes, reaching $82.6 \%$. It is followed by $\mathrm{CH}_{4}$-SOFC, which has a lower exergy efficiency of $74.9 \%$ mainly because of the energy loss in the $\mathrm{CO}_{2}$ capture unit.

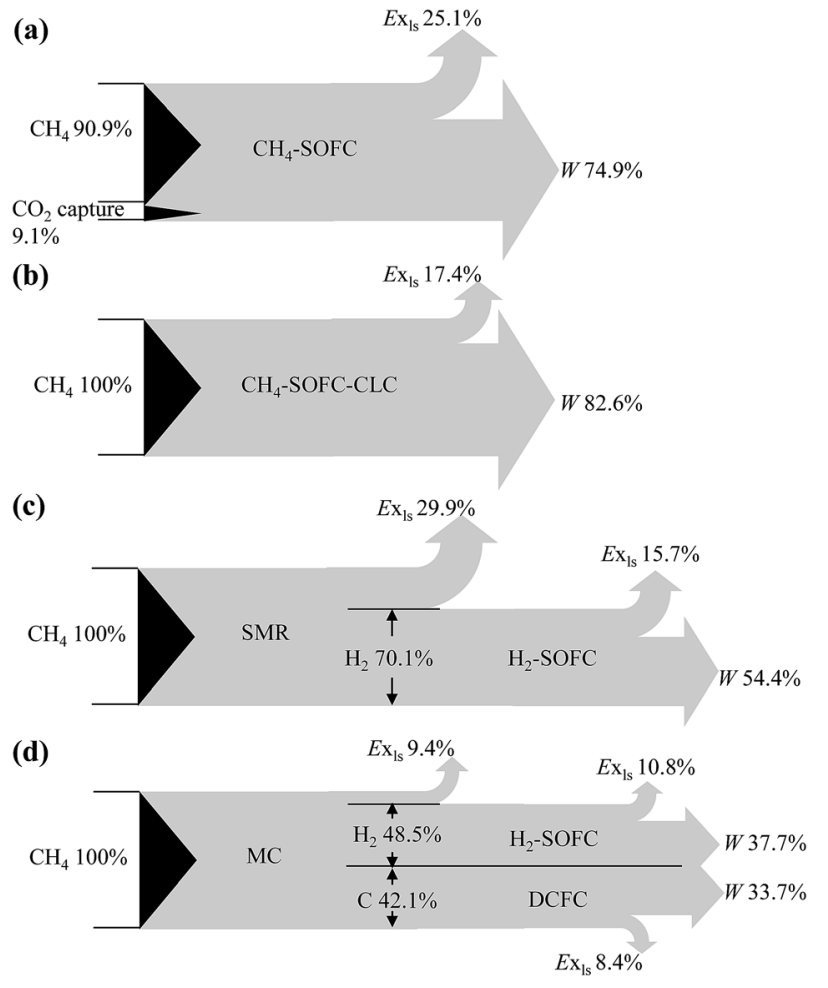

Fig. 11 Simplified exergy flow diagrams of the four SOFC processes using $\mathrm{CH}_{4}$ as the original fuel.

MC-SOFC-DCFC obtains an overall exergy efficiency of $71.4 \%$, which is in good consistent with that of Liu's MC-IRSOFC-DCFC model (68.2\%). ${ }^{8}$ SMR-SOFC has the lowest efficiency of $54.4 \%$ which is $17 \%$ lower than that of MC-SOFC-DCFC. SMR process alone causes a loss of $29.9 \%$ of total exergy delivered into the whole process, leading to the low exergy efficiency of SMR-SOFC. MC process has a higher exergy efficiency than SMR mainly owing to the relatively higher reactant utilization of MC. Theoretically, in MC methane can be totally utilized to produce hydrogen and carbon; while in SMR, the carbon in methane is reacted to carbon dioxide without the capability of producing electricity. Besides, more heat is required for the SMR reaction than the decomposition of methane, which results in a higher fraction of methane consumption in heat provision and increases the complexity of heat integration, leading to further decrease in the exergy efficiency of the whole SMR-SOFC system.

\section{Conclusions}

Exergy analysis is carried out on four different solid oxide fuel cell (SOFC) processes which use methane as the original fuel. The effect of operating parameters on the performance of $\mathrm{CH}_{4}$-SOFC is also examined.

The $\mathrm{CH}_{4}$-SOFC-CLC system and $\mathrm{CH}_{4}$-SOFC system without $\mathrm{CO}_{2}$ capture have similar high exergy efficiency, $81.4 \%$ and $81.6 \%$ respectively. When a $\mathrm{CO}_{2}$ capture unit is attached to the latter, its exergy efficiency is decreased by $7.5 \%$. The $\mathrm{H}_{2}$-SOFC system has an exergy efficiency of $77.6 \%$ which is lower than 
that of $\mathrm{CH}_{4}$-SOFC-CLC system. It is also found that lower cell temperature and higher cell pressure result in increased overall exergy efficiency of $\mathrm{CH}_{4}$-SOFC.

When the $\mathrm{H}_{2}$ production processes are integrated into the $\mathrm{H}_{2}$-SOFC system, the formed SMR-SOFC and MC-SOFC-DCFC processes have even lower efficiencies, as a large amount of exergy is destroyed in $\mathrm{H}_{2}$ production. MC-SOFC-DCFC obtains an overall exergy efficiency of $71.4 \%$, which is $17 \%$ higher than that of SMR-SOFC $(54.4 \%)$. This is mainly contributed to the higher exergy efficiency of MC than SMR.

The results of this investigation demonstrate that the development of methane directly fuelled SOFC, decreasing its operating temperature and proper capture of $\mathrm{CO}_{2}$ are key technologies to improve the energy performance of SOFC systems.

\section{Acknowledgements}

The authors gratefully acknowledge the support of the Fundamental Research Funds for the Central Universities (FRF-TP-16036A1).

\section{References}

1 S. Park, J. M. Vohs and R. J. Gorte, Direct oxidation of hydrocarbons in a solid-oxide fuel cell, Nature, 2000, 404, 265-267.

2 F. Calise, M. Dentice d'Accadia, A. Palombo and L. Vanoli, Simulation and exergy analysis of a hybrid solid oxide fuel cell (SOFC)-gas turbine system, Energy, 2006, 31, 3278-3299.

3 J. Huijsmans, F. Van Berkel and G. Christie, Intermediate temperature SOFC - a promise for the 21st century, J. Power Sources, 1998, 71, 107-110.

4 A. P. Simpson and A. E. Lutz, Exergy analysis of hydrogen production via steam methane reforming, Int. J. Hydrogen Energy, 2007, 32, 4811-4820.

$5 \mathrm{~J}$. Fan and L. Zhu, Performance analysis of a feasible technology for power and high-purity hydrogen production driven by methane fuel, Appl. Therm. Eng., 2015, 75, 103-114.

6 A. M. Dunker, S. Kumar and P. A. Mulawa, Production of hydrogen by thermal decomposition of methane in a fluidized-bed reactor-effects of catalyst, temperature, and residence time, Int. J. Hydrogen Energy, 2006, 31, 473-484.

7 Q. Liu, Y. Tian, H. Li, L. Jia, C. Xia, L. T. Thompson, et al., High efficiency chemical energy conversion system based on a methane catalytic decomposition reaction and two fuel cells: part I. Process modeling and validation, $J$. Power Sources, 2010, 195, 6539-6548.

8 Q. Liu, Y. Tian, H. Li, L. Jia, C. Xia, L. T. Thompson, et al., High efficiency chemical energy conversion system based on a methane catalytic decomposition reaction and two fuel cells: part II. Process exergy analysis, J. Power Sources, 2010, 195, 6532-6538.

9 Z. Wang, W. Fan, G. Zhang and S. Dong, Exergy analysis of methane cracking thermally coupled with chemical looping combustion for hydrogen production, Appl. Energy, 2016, 168, 1-12.
10 L. Zhu, P. Jiang and J. Fan, Comparison of carbon capture IGCC with chemical-looping combustion and with calciumlooping process driven by coal for power generation, Chem. Eng. Res. Des., 2015, 104, 110-124.

11 H. J. Ritcher and K. F. Knoche, in Reversibility of combustion process, ed. R. A. Gaggioli, ACS Symposium Series 235, Washington DC, 1983, pp. 71-85.

12 J. Adanez, A. Abad, F. Garcia-Labiano, P. Gayan and F. Luis, Progress in chemical-looping combustion and reforming technologies, Prog. Energy Combust. Sci., 2012, 38, 215-282.

13 M. Tang, L. Xu and M. Fan, Progress in oxygen carrier development of methane-based chemical-looping reforming: a review, Appl. Energy, 2015, 151, 143-156.

14 M. Ishida, D. Zheng and T. Akehata, Evaluation of a chemical-looping-combustion power-generation system by graphic exergy analysis, Energy, 1987, 12, 147-154.

15 M. Anheden and G. Svedberg, Exergy analysis of chemicallooping combustion systems, Energy Convers. Manage., 1998, 39, 1967-1980.

16 M. Rydén and A. Lyngfelt, Using steam reforming to produce hydrogen with carbon dioxide capture by chemical-looping combustion, Int. J. Hydrogen Energy, 2006, 31, 1271-1283.

17 M. R. Rahimpour, M. Hesami, M. Saidi, A. Jahanmiri, M. Farniaei and M. Abbasi, Methane steam reforming thermally coupled with fuel combustion: application of chemical looping concept as a novel technology, Energy Fuels, 2013, 27, 2351-2362.

18 J. A. Medrano, V. Spallina, M. van Sint Annaland and F. Gallucci, Thermodynamic analysis of a membraneassisted chemical looping reforming reactor concept for combined $\mathrm{H}_{2}$ production and $\mathrm{CO}_{2}$ capture, Int. J. Hydrogen Energy, 2014, 39, 4725-4738.

19 M. Rydén, Hydrogen production from fossil fuels with carbon dioxide capture, using chemical-looping technologies, PhD thesis, Chalmers University of Technology, Sweden, 2008.

20 P. Roohi, R. Alizadeh and E. Fatehifar, Thermodynamic study of transformation of methane to synthesis gas over metal oxides, Int. J. Thermophys., 2015, 36, 88-103.

21 S. Chen, N. Lior and W. Xiang, Coal gasification integration with solid oxide fuel cell and chemical looping combustion for high-efficiency power generation with inherent $\mathrm{CO}_{2}$ capture, Appl. Energy, 2015, 146, 298-312.

22 P. G. Bavarsad, Energy and exergy analysis of internal reforming solid oxide fuel cell-gas turbine hybrid system, Int. J. Hydrogen Energy, 2007, 32, 4591-4599.

23 S. Motahar and A. A. Alemrajabi, Exergy based performance analysis of a solid oxide fuel cell and steam injected gas turbine hybrid power system, Int. J. Hydrogen Energy, 2009, 34, 2396-2407.

24 U. Desideri and A. Paolucci, Performance modelling of a carbon dioxide removal system for power plants, Energy Convers. Manage., 1999, 40, 1899-1915.

25 S. McIntosh and R. J. Gorte, Direct hydrocarbon solid oxide fuel cells, Chem. Rev., 2004, 104, 4845-4866.

26 J. Szargut, D. R. Morris and F. R. Steward, Exergy analysis of thermal, chemical, and metallurgical processes, Hemisphere Publishing Corporation, New York, 1987. 
27 M. Rosen, Thermodynamic investigation of hydrogen production by steam-methane reforming, Int. J. Hydrogen Energy, 1991, 16, 207-217.

28 N. Muradov, Hydrogen via methane decomposition: an application for decarbonization of fossil fuels, Int. J. Hydrogen Energy, 2001, 26, 1165-1175.
29 X. Li, Z. Zhu, J. Chen, R. De Marco, A. Dicks, J. Bradley, et al., Surface modification of carbon fuels for direct carbon fuel cells, J. Power Sources, 2009, 186, 1-9.

30 G. A. Hackett, J. W. Zondlo and R. Svensson, Evaluation of carbon materials for use in a direct carbon fuel cell, J. Power Sources, 2007, 168, 111-118. 